\title{
Economies of (Alleged) Deviance: Sex Work and the Sport Mega-Event
}

\author{
Amanda De Lisio $^{1,2}$ (D) Philip Hubbard ${ }^{3}$. Michael Silk ${ }^{1}$ \\ Published online: 1 February 2018 \\ (C) The Author(s) 2018. This article is an open access publication, corrected publication February/2018
}

\begin{abstract}
Based on ethnographic data collected during the 2014 FIFA World Cup and 2016 Olympic Games in Rio de Janeiro, Brazil, this article is interested to examine urban processes which reinvent the changing (sexual) landscape. Focusing on the way (host) cities shape sex work both imaginatively and physically, we explore the (lived) realities of neoliberal imaginaries that shape urban space. Often thought to exist in the urban shadow as an absent-presence in cosmopolitan processes, we demonstrate the manner in which sexualized and racialized women creatively resist the political and economic trajectories of neoliberal urbanism that seek to expropriate land and dispossess certain bodies. In the context of Rio de Janeiro - as in other host cities - this is particularly evident in the routine encounter between sexual minorities and local law enforcement. Mindful of the literature on state incursion into social-sexual life, we remain attentive to the everyday strategies through which those deemed sexually deviant and/or victim navigate local authorities in search of new opportunities for economic salvation in the midst of the sport mega-event.
\end{abstract}

Keywords Sport mega-event $\cdot$ Securitization $\cdot$ Sexscape $\cdot$ Informal economies $\cdot$ Rio de Janeiro

\section{Introduction}

As a rapacious convergence of global-corporate interest with the more locally embedded desire for foreign investment and tourism, the sport mega-event (SME) is emblematic of late capitalism. This convergence is especially evident in event rhetoric littered with fantasies of grandiose capital accumulation and hypermodern urban infrastructure made synonymous with sport-prompted construction. In staging the $2007 \mathrm{Pan} /$

Amanda De Lisio

adelisio@bournemouth.ac.uk

Philip Hubbard

philip.hubbard@kcl.ac.uk

Michael Silk

msilk@bournemouth.ac.uk

1 Department of Sport \& Physical Activity, Faculty of Management, Bournemouth University, Poole, UK

2 Observatório da Prostituição, Universidade Federal do Rio de Janeiro (Federal University of Rio de Janeiro), Rio de Janeiro, Brazil

3 Department of Geography, King's College London, London, England, UK
Parapan American Games, 2011 Military World Games, 2013 Confederations Cup, 2014 FIFA World Cup, and 2016 Summer Olympic/Paralympic Games, Rio de Janeiro sought to aggressively reproduce and reimagine Brazil and Latin America to the (watching) world. Celebrated as a commercially viable and socially pacifying institution, the sport event (implanted from the Global North) rationalized urban reform - from the downtown core to maligned peripheriespromising the injection of global-tourism capital, increased access to health and wellness facilities, and new opportunities for more environmentally sustainable transit.

This is typical of the "mega-event strategy" in that it has continued to allow "powerful interests in cities to attach their agendas to the Olympic process, creating the perfect policy mechanism for ensuring a growth agenda" (Andranovich, Burbank, \& Heying, 2001, p. 127). In Rio de Janeiro, the sport mega-event influenced a wave of pro-growth urban processes, with Jordi Borja, planning consultant and former deputy mayor of Barcelona, who collaborated with municipal authorities on the creation of the Strategic Plan of the City of Rio de Janeiro (Plano Estratégico da Cidade de Rio de Janeiro). More than a mere catalyst within the Strategic Plan, the sport mega-event was touted as a crucial vehicle (our emphasis) to effect urban transformation. Borja exported the mega-event 
dream and legitimated sport as a desirable chance to restore tourism, attract foreign capital, and snare domestic investment (Torres Ribeiro, 2006). Through the Strategic Plan, the megaevent became the new language through which political parties in power could "civilize" the public sphere.

However, as event literature and attendant media describe, the sport mega-event has also become synonymous with spatial displacement, removal, and erasure (e.g. Kennelly \& Watt, 2011; Silk, 2014). As observed in the wake of a bid announcement, event construction is perpetually paired with policies that dismantle social welfarism, promote entrepreneurialism of a certain kind, and mobilize new strategies of social control to securitize, sanitize, and spectacularize the cityscape (Hodkinson, 2011; Paton, Mooney, \& McKee, 2012; Peck, Theodore, \& Brenner, 2009). The construction of hypermodern sport stadia and the associated "playscape" for tourist and consumer classes relies upon the removal of "disposable" bodies - setting in motion a wave of corporate gentrification, rippling from the epicentre of host cities to peripheries, displacing the very communities purported to benefit from event investment. Gentrification and urban renewal manifest through "revanchist" strategies: such as the appropriation of public space (see Silk \& Andrews, 2008; Smith, 1996), the regulation of neighbourhood space (see Raco, 2012), and the newly invented technologies of social control that disproportionately target "quality of life" offense (e.g. street prostitution, loitering, disorderly conduct, vagrancy) to secure a middle-class tourist aesthetic (e.g. Judd \& Simpson, 2003; Paton et al., 2012; Silk, 2007, 2011; Silk \& Amis, 2005; Smith \& Fox, 2007; Whitson \& Macintosh, 1996). Sexualized and racialized minorities (those discursively constructed as marginal due to their sexual orientation and/or sexualized labour) are especially targeted in these revanchist urban processes (Hubbard \& Wilkinson, 2015; Matheson \& Finkel, 2013). Of interest to this article is the discursive and material construction of those involved in sexual commerce as either "deviant" or "victim" in the humanitarian crusade known to follow the hypermasculine sport spectacle (see Fig. 1).

Despite repeated ridicule, sexual/erotic labour has still survived, even thrived - and maintained the "erotic nationalism" (Nyeck, 2013) so-often endorsed across the (trans)national tourism sector. We are attentive to these ambivalent realities as there is little work to detail the impact of the sport megaevent on informal sexual economies - somewhat surprisingly due to the recurrent investment in charitable agencies that seek to end the (still unfounded) increase in sexual exploitation (Bird \& Donaldson, 2009; Richter, Luchters, Ndlovu, Temmerman, \& Chersich, 2012). That the sport mega-event will accelerate exclusionary processes within host cities is not denied. The host context is far from a neutral backdrop. As an intervention onto local land, the event is not merely a neoliberal mechanism of spatial displacement, removal, and erasure; it is also an intervention onto local bodies. As Puri (2016, p. 318 ) notes, "neoliberalism is about bourgeois subjects, bourgeois sensibilities, and bourgeois spaces [through which] the terrain of sexuality has all too frequently facilitated neoliberal expansion by sharpening the wedges of class, gender, racialization, and rightwing nationalisms in urban spaces." Those involved in sexual commerce are representative of bodies/people which are subject to heightened control. Specific to this article, we maintain that the competitiveentrepreneurial mindset and expropriation of needed resource material celebrated in the mega-moment is not extended to all - and observe the spatial governmentality of certain newly lucrative host communities.

Through an integrated methodological approach — which relies upon fieldwork conducted in Rio de Janeiro since April 2014 - we thus start to fill the void between ambiguous legislation and everyday action. Through the close interrogation of event processes that strike local bodies, we attempt to demonstrate the impact of 2014/2016 construction on the attendant sexual landscape. While we predominantly work with data collected in 2014/2016 host communities, we contrast these realities with stories from former host cities in order to detail the strategies used to regulate (sexually) marginalized bodies in the context of the sport mega-event. Attention to former host cities allowed us to trace commonalities experienced within Rio de Janeiro to inform strategies for the future. As we conclude, more work is needed to better understand the intersection between vaguely worded prostitution legislation and event-led construction, which coalesce to construct certain sexual identities as deviant/victim in promotion of a neocolonial-capitalist agenda.

\section{Sex Work in the Context of "Entrepreneurial Exceptionalism"}

Across host communities, nongovernmental and private agencies invested in the event decide the vision for urban revitalization, typically leaving few opportunities for the public to participate in processes that drastically transform their city. A "state of exception" is seen to unfold as private interest is positioned outside the traditional rule of law. ${ }^{1}$ Mega-event literature has often referenced Agamben (2005) to demonstrate the manner in which FIFA and the IOC have bound host cities to processes that redefine "citizenship" (Ong, 2006), reshape urban realities (Gaffney, 2010), and restructure

\footnotetext{
${ }^{1}$ It is somewhat salient to note that sport is not the sole mechanism through which a "state of exception" could be established. For example, the recent Trans-Pacific Partnership (TPP) and Transatlantic Trade and Investment Partnership (TTIP), like the North American Free Trade Agreement (NAFTA), aim to restructure international commerce and trade so that capitalist expansion can flourish without the encroachment of countries' sovereign law.
} 
Fig. 1 From left to right, campaign against the sexual exploitation of children advertised throughout 2014 FIFA host communities; United Nations Global Initiative to Fight Trafficking (GIFT Box) introduced in red-light district, Vila Mimosa (discussed below); letter to detail the closure of a well-known bar in Copacabana due to allegation of sexual exploitation. Photo credit: Amanda De Lisio
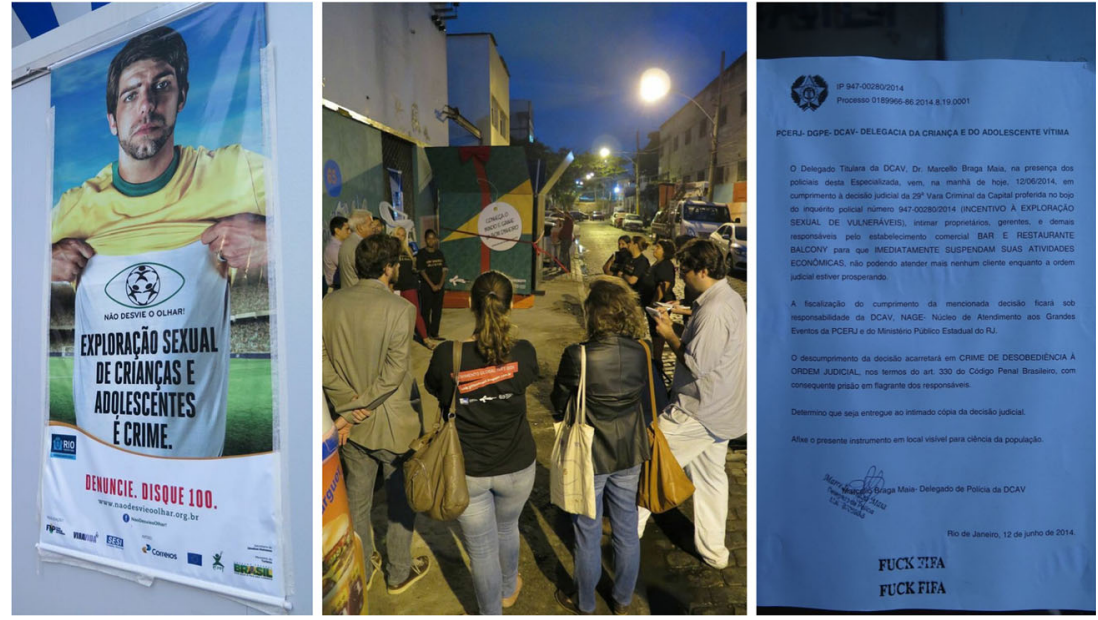

strategies of local law enforcement (Vonn, 2009). Yet for those within the urban shadow, such processes of capitalist expansion are far from exceptional: Exceptionalism realized through law has been a tool of colonial conquest for centuries. Pavoni (2013) has described the sport mega-event as not an exception but rather as an "explicitation" of emergent processes of social control. In this article, we follow Pavoni in treating exceptionalism as not unique to the sport mega-event but an amplification of tendencies inherent to neoliberal urban order - that is to recognize that contemporary cities are built on the continual logics of legal suspension and displacement.

In the context of Rio de Janeiro, Gaffney (2010) has documented the exceptionalism/explicitation associated with the sport mega-event. In November 2015, the Comitê Popular Rio Copa e Olimpíadas [Popular Committee for the World Cup and Olympics in Rio de Janeiro] launched their fourth dossier, which detailed event-led processes of exceptionalism (i.e. lack of information, participation, and transparency in relation to FIFA and Olympic construction) and dubbed Rio de Janeiro the cidade de exceção [city of exception] (2015, p. 8). Specific to the geographies of law within host cities, the World Cup Law (Law No. 12.663), enacted in 2011, defined FIFA territories as the area within a $2-\mathrm{km}$ radius of each venue. In legal documentation, FIFA-imposed boundaries were discussed as an "area of exclusivity" in which the street sale of nontrademarked commodities was made criminal. Those within the informal sector that worked near FIFA stadia were forced to obtain "official" authorization and purchase/sell FIFAsponsored commodities, which still did not guard against removal, and therefore further threatened already precarious, low-income labour. It is important to mention that despite the fact that the IOC and FIFA are afforded opportunities to rewrite sovereign law in the Host City Contract, neither has legally required cities/countries to adhere to a specific environmental and/or social justice standard.

The ambiguous nature of prostitution legislation/ enforcement is a fertile realm for FIFA/IOC exceptionalism to take hold. Former (and selected future) host cities have ranged from those that completely oppose sex work, to those partially tolerant (through partial decriminalization), to those open/supportive. For instance, China (2008 Summer and 2022 Winter Olympics), Qatar (2022 FIFA World Cup), Russia (2014 Winter Olympics and 2018 FIFA World Cup), and most cities in the USA maintain a completely criminalized regime in which the sale and purchase of sex are illegal under the criminal code. This, however, is in stark contrast to the legalized regime in host countries such as Germany (2006 FIFA World Cup) and Greece (2004 Summer Olympics) in which prostitution is legally permissible and regulated (e.g. a brothel can obtain a permit, if registered with the state; a sex worker can obtain a license, if subject to routine health inspection). Countries/cities in between these legal polarities have also been selected to host. Canada (2010 Winter Olympics), for example, followed a partial decriminalization regime in which activities related to prostitution remain criminalized (communication, facilitation, etc.) but not the actual sale of sex. The universal ambiguities of prostitution policies/law have historically been used to facilitate an urban agenda known to privilege (private) property and profit over the democratic access/ use of land and resource material.

At least since the 2004 Summer Olympic Games hosted in Athens, Greece, popular anxieties related to human trafficking for sexual (not labour) exploitation have emerged in relation to the sport mega-event. Vulnerable women and children forced to endure unfathomable sexual torture are thrust into the media spotlight, often obscuring actually existing realities of state-sanctioned violence enacted upon local land and bodies (such as the exploitation of labour in the building of stadia, or the expropriation of land from vulnerable communities). Inevitably, this moral crusade has conflated adult, consensual sex work with sexual exploitation, and rationalized the repeated and harmful criminalization of sex industries. Whereas the media is quick to circulate time-sensitive stories of human trafficking for sexual exploitation and forced prostitution, no 
such case was found in relation to the 2014 FIFA or 2016 IOC event (Blanchette \& da Silva, 2016). Heightened (sex) surveillance failed to reveal the reported 2000-60,000 women and children trafficked and exploited for mega-event men, with research conducted in host cities indicating no increase in human sex trafficking at the 2004 Summer Olympics (Athens, Greece), 2010 Winter Olympics (Vancouver, Canada), or 2010 FIFA World Cup (South Africa). At the 2006 FIFA World Cup (Germany), five people were alleged to have been sex trafficked. Of these five, four were adult women (two from Bulgaria, one from the Czech Republic, and one from Germany), while one man was found from Hungary.

Whilst every case of human trafficking is worth careful attention and action, we question the extent to which (trans)national agencies and political parties in power offer adequate protection for those found to be trafficked amidst mega-parties. We are also critical of the state-sanctioned violence directed at those involved in adult, consensual sexual/ erotic labour that is framed as either crime reduction or humanitarian aid (Matheson \& Finkel, 2013; Hubbard \& Wilkinson, 2015). The moral entrepreneurialism pursued by religious-affiliated agencies based in the Global North, padded by the more localized effort of law enforcement authorities in the Global South, rather than stimulate democratic debate with those targeted in action, rationalize the imposition of certain neocolonial-capitalist fantasies. Bizarre that this convergence does not target the labour exploitation observed in stadia construction (Pattisson, 2013) or identification of athletic talent (Cornelissen \& Solberg, 2007; Maguire \& Pearton, 2000) nor challenge the continued exploitation of land across the Global South. Nevertheless, revanchist strategies combined with humanitarian aid continue to create unintended legacies across host cities. In this article, we attend to the spatial impact of strategies which seek to "rescue" and/or "police" informal sexual economies, particularly as manifest in the life of Brazilian women.

\section{Method}

Data in this paper was drawn from an integrated method that included the following: (i) document analyses of prostitution and/or anti-trafficking informational material; (ii) the collection of observational data; (iii) context-building conversational interview data (informal and formal) with those identified in the field (Hammersley \& Atkinson, 2007); and (iv) audiovisual data (photo, video, audio) recorded to supplement field diaries and add to the overall documentation of urban reform (Pink, 2013). Since April 2014, the lead author has lived/ worked in Rio de Janeiro to interview over 100 women and observe sex-related businesses in the context of 2014 and 2016 urban reform. Data collection occurred in conjunction with the Prostitution Policy Watch [PPW or Observatório da Prostituição], an extension project of the Metropolitan Ethnographic Lab (LeMetro/IFCS) at the Federal University of Rio de Janeiro. PPW is a network of (inter)national allies in academia (e.g. from the Federal University of Rio de Janeiro, Fluminense Federal University, State University of Campinas, Columbia University, Williams College, and the University of Toronto) and the broader public/activist sphere (e.g. Davida/ Daspu, the Brazilian Interdisciplinary Association of AIDS, and the Brazilian Network of Prostitutes). Pivotal to data collection, this collaborative afforded the needed access, expertise, and accompaniment in the field.

Data collection focused on different zonas [zones] known for sexual commerce in Rio de Janeiro so as to trace the broader spatial displacement/migration of sex in the city. This spatial inflection allowed purchase on the manner in which women involved in sexual commerce-as a diverse, multifaceted, and site-specific market — overcome the repressive policies and moral indignation directed at sexual minorities to make the most of the entrepreneurial moment. That said, the analysis of data was attentive to similarities between/among the female sex worker-chastised for her (sexual) entrepreneurialism - and the entrepreneurial men that work for FIFA and the IOC. Similar to Pavoni and Citroni (2016), we view the event as conflict - radically political, it is able to rearticulate the atmosphere and rhythm of the cityscape, "mak[ing] visible what had no business being seen, and mak[ing] heard a discourse where once there was only place for noise" (Rancière, 1995, p. 30). We thus do not retell stories about the repressive, (supra)imposed nature of the event but rather demonstrate the manner in which the sport mega-event offered newly contestable terrain in which those discursively constructed as vulnerable and/or deviant realize economic salvation via mega-parties. We understand that while the reconstruction of urban space does fit the familiar colonial-capitalist mold, it is far too convenient to assume only the elite realize imaginaries and reinvent the cityscape. An urban intervention such as the sport mega-event will create different possibilities/ opportunities for the entire populace.

\section{Sexual Entrepreneurialism in Rio de Janeiro}

Before we discuss the impact of 2014/2016 event construction on the "host" sexscape, it is necessary to offer a brief overview of the historic insertion of prostitution within the urban fabric of Rio de Janeiro, and Brazil more broadly. Prostitution has never been outlawed in Brazil, yet the activities that surround the sale of sex - such as operating a brothel or employing a prostitute in any way - are illegal. The quasi-legal nature of the profession has led to circumstantial enforcement, most readily influenced by the shifting public discourse, cash flow, and the willingness of parties to negotiate with parties in 
power (Blanchette \& da Silva, 2010). On the one hand, it could be said that Brazil actively supported sex work, maintaining agencies that act in support of the sex worker labour movement, and in 2005 rejecting $\$ 40$ million from the Bush administration (US Agency for International Development in American AIDS grant) to protest the requirement that recipient countries first sign a pledge "condemning" prostitution (Mitchell, 2011). Yet, despite evidence of its sporadic inclusion in formal-political debate, it is more accurate to maintain that prostitution has thrived in the urban shadows as not only a criminalized form of labour but also a lucrative component of the broader service sector, especially that known to coalesce around the male-dominated sport mega-event. Nevertheless, prior to the 2014 FIFA World Cup, sex-related businesses faced heightened surveillance and harassment from municipal authorities across a range of host communities (Mitchell, 2016). In conjunction with political parties in power, media (both national and international) published sensationalist stories of sex trafficking and slavery aimed at promoting anti-prostitution sensibilities and endorsing abolitionist strategies, while police remained a permanent fixture within touristfriendlier sex zones such as those located in the South Zone (see Fig. 2). These activities were not dissimilar to the punitive processes evident in Vancouver 2010, where those involved in sex work reported a heightened amount of police harassment without arrest and increased difficulty in meeting clientele (Deering et al., 2013), as well as those in London 2012, where increased surveillance of sex work on the pretext of identifying trafficked women and children resulted in the closure of several businesses and erosion of sex worker allies and support agencies (Hubbard \& Wilkinson, 2015).

To understand the varied geographies of sexual commerce in Rio de Janeiro- as with other former and future host cities-is to recognize that sex work is territorially defined. Commercial sex is able to exist within a "moral geography"

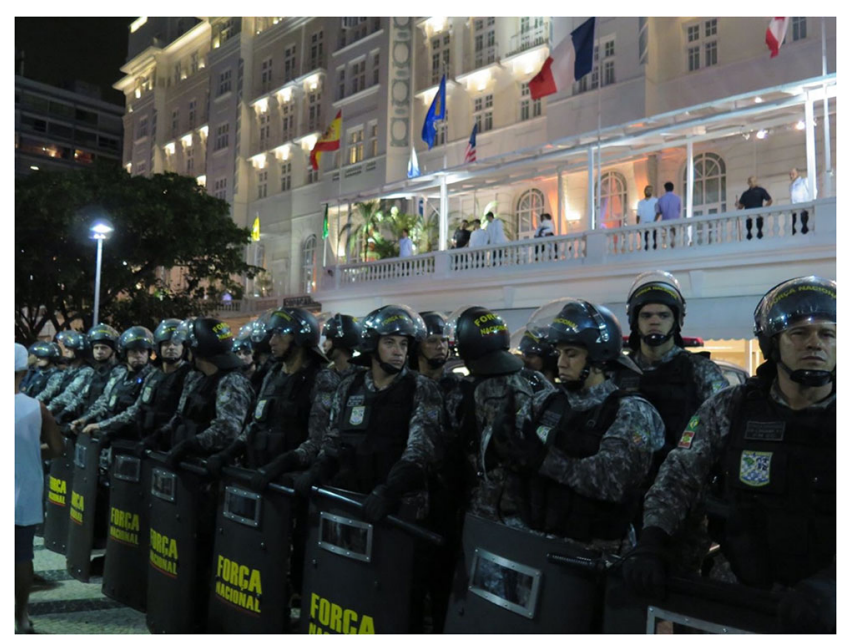

Fig. 2 Copacabana Palace, residence of the "FIFA family" during the month of the FIFA World Cup. Photo credit: Amanda De Lisio that is reflective of the dominant morale of the urban locale (Hubbard, 2016). As such, it is common for certain (sex) businesses to be allowed in one neighbourhood whilst denied from another. As Blanchette and da Silva (2010) have explained: "Rio de Janeiro, by any definition, is not just a singular and homogeneous sexscape... but is better conceived of as a series of overlapping and intertwining commercial sex scenes of almost bewildering variety and complexity" (p. 132). Thus, while it is difficult to observe each zone in isolation - due to the fact that sex work is highly transient and occasionally accidental - we focus on businesses/communities effected in 2014/2016 reform (i.e. Niterói, Centro/Downtown, Vila Mimosa, and Copacabana). This spatial inflection has allowed us to sketch the manner in which event construction can (and will) impact the entire archipelago of commercial sex in (host) cities. Following Loopmans and Van den Broeck (2011), in the near future, we intend to delve into territorially anchored political complexities created in the realization of certain imaginaries to trace the opportunities in which the sexual entrepreneur is asked to either conform or disappear into the urban shadow. Nevertheless, in this article, we are still cautious to note the extent to which those deemed sexually "deviant" and/or marginal still create opportunities to reimagine, reconstitute, and remake the world around them.

\section{Niterói}

The Rio de Janeiro Metropolitan Region is comprised of 21 municipalities, of which Niterói is one. Located on the Guanabara Bay, it is a consolidated enclave for the Brazilian middle-to-upper classes. Prior to the 2014/2016 bid announcement, it benefited from industries that were bolstered by federal policies which catered to multinational companies such as Petrobras. With the event came new incentive to attract entertainment tourism. The "revanchist" strategies introduced in the construction of Porto Maravilha [Marvellous Port] in downtown Rio de Janeiro consolidated the model and vision for Niterói to act. Similar in aesthetic (sleek, modernized architecture - with modified height limit, barbershop, museum, and commissioned artwork), the reliance on public-private finance, and expectation (future tourist hub for amanhã [tomorrow] and attractor of foreign investment), Niterói came to absorb much of the FIFA/IOC overflow. The revitalization of the historic downtown core also came to demonstrate the limit of neoliberal-entrepreneurialism. Once home to the Caixa, the most concentrated sex zone since the end of the second dictatorship (1964-1985) (see Fig. 3), the recent revitalization effort failed to include sexual commerce in fantasies of the future. In May 2014, women worked in the lower half of the high-rise. Some pocketed $\mathrm{R} \$ 8000$ (approximately USD\$4000) a month. However, most made salaries well over minimum wage (R $\$ 880 /$ month or USD $\$ 228 /$ month). Down the road from the Caixa stood the 76th Civil Police Precinct. 


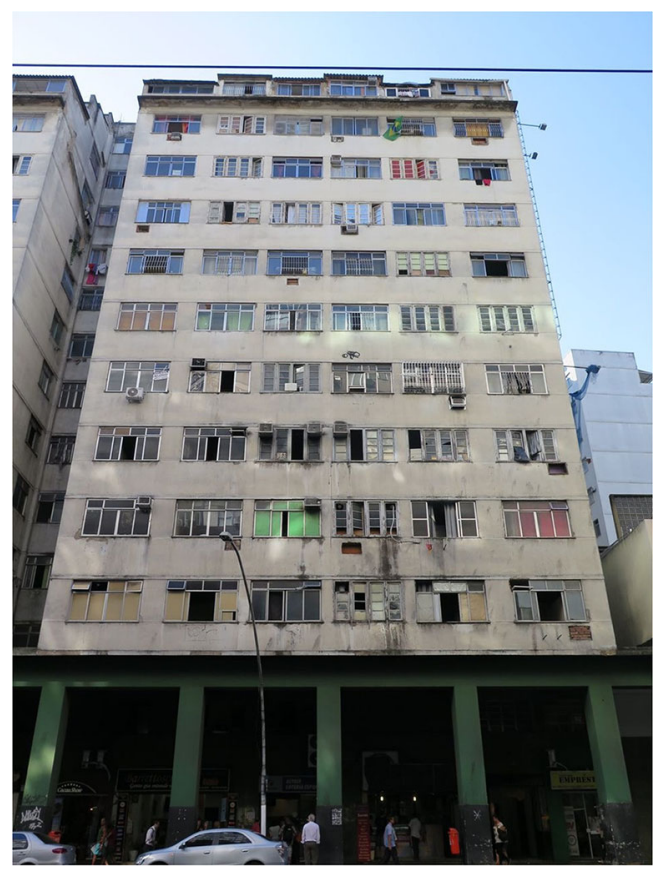

Fig. 3 Midday at the Caixa, post-raid. Photo credit: Amanda De Lisio

Police served as regular clientele, and the precinct collected a generous monthly stipend from each apartment rented/owned for sex work.

The launch of 2016 Olympic urbanism welcomed a new chief of police in March 2014. On April 1, 2014, the police raided the commercial sex venue. Eleven women were arrested and two (accused of sexually exploiting each other) were taken to Bangu Penitentiary Complex, a maximumsecurity prison located in the West Zone of Rio de Janeiro. Bangu is infamous within the Brazilian prison system: a system internationally known for torture, ill treatment, and an overall destitute state (see Wacquant, 2008). ${ }^{2}$ On April 16, 2014, more than 200 women protested the false accusation, arrest, and detainment. Yet on May 23, 2014, heavily armed men in military armor raided the Caixa, and approximately 120 women were evicted (see Fig. 4). The public defender assigned to the case declared at the State Public Assembly that the raid was "completely illegal" but authorities were never held accountable. The criminal allegation of sexual exploitation legitimated the raid but no one confirmed the claim. Marcelo Freixo, president of the Comissão de Defesa Direitos Humanos e Cidadania [Commission for Human Rights] observed:

It is certainly not a coincidence that this happened now.

Downtown Niterói is going through a period of massive

\footnotetext{
${ }^{2}$ The Bangu Penitentiary Complex is now home to the former governor of Rio de Janeiro, Sérgio Cabral. In 2016, it also temporarily housed the president of the Olympic Council of Ireland, Pat Hickey, charged with ticket touting, ambush marketing, theft, tax evasion, money laundering, and criminal association.
}

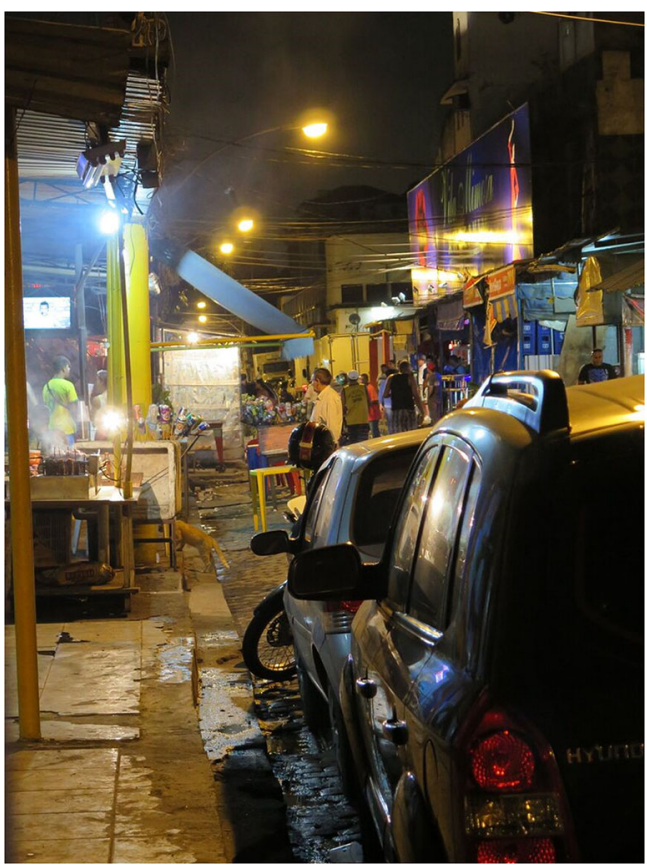

Fig. 4 Vila Mimosa, after pre-World Cup clean-up effort. The billboard on the right was erected the weekend before the 2014 opening game. The billboard was paid for by AMOCAVIM (the Association of Condominium Residents and Friends of Vila Mimosa). Photo credit: Amanda De Lisio

reform, with large real estate interest. It is nothing new for Brazil or unique to the twenty-first century that the first to be removed are those unwanted in a supposedly "modern" centre. The prostitute is the first on the list to be barred from the "modern" city. (Personal communication, June 4, 2014)

In the aftermath of the eviction, women were forced to resettle elsewhere. As Jessica commented, "If we worked anywhere near there... If a girl got in the car there, they would be charged R $\$ 1000$. So, everyone went to work somewhere else" (Jessica, personal communication, September 24, 2016). The Caixa women later found in Centro, Vila Mimosa, and Copacabana held nostalgic memories of Niterói-most celebrated the autonomy, collegiality, and overall management of the venue. Despite momentary collapse and routine displacement, it was evident that most Caixa women continue to work within sexual commerce, albeit in a newfound urban corner.

\section{Centro/Downtown}

Opposite Niterói, across the Guanabara Bay, is downtown Rio de Janeiro. Once home to the historic red-light district, the Mangue [Marsh], now renamed/relocated to Vila Mimosa, Centro is the proverbial heart for (trans)national desire (Blanchette \& da Silva, 2010). Prior to 1920, extralegal policies established the Mangue in order to regulate (predominately black) bodies and illicit desire through spatial containment. 
Subject to the discretionary control of local law enforcement, women were able to work in sex industries, albeit intermittently subject to relocation and moral hygienization. With the highly anticipated visit from King Albert and Queen Elisabeth of Belgium, the desire to showcase "Order and Progress" [Ordem e Progresso], as emblazoned on the national flag, influenced political action to officially eradicate the Mangue from the downtown port area (see Caulfield, 1997). Despite relocation of the red-light district, the seemingly demure downtown has never ceased to be a hub for sexual commerce; from "terma" (sauna, complete with bar and discotheque), brothel, erotic theatre, and love hotel, to "privé" (massage parlour operating in rented, high-rise apartment space) or "fast foda" ("fast fuck" in English), sex-related businesses have continued to coexist amid the more "respectable" formal business sector.

For the duration of the 2014 FIFA World Cup (June 12 to July 13, 2014), formal businesses located downtown were closed for holiday, which forced the closure of several sexrelated businesses in the area too. As Thayná explained, "Business was slow when Brazil played. Everyone was on holiday. I expected to do better. During the Olympics, it was the same. I served maybe one or two gringos. One from the Olympic Federation! He gave me a hat." (Personal communication, March 6, 2017). The closure of businesses for FIFA/ IOC parties mimicked the realities of those involved in sexual commerce in 2010 FIFA (South Africa), 2010 Olympic (Vancouver), and 2012 Olympic (London) host communities, which observed diminished clientele due to event construction, road closure and traffic, increased police presence (and harassment), and irregular weekday parties (see Deering et al., 2013; Matheson \& Finkel, 2013). Post-event interview data confirmed that women were dissatisfied with the lack of (foreign and domestic) clientele. Construction of the Olympic Boulevard downtown, near Praça Mauá, home to the Olympic Fan Zone, bolstered optimism for 2016 business. Olympic construction established the Port Urban Development Company (CDURP), the largest public-private partnership in Brazilian history, which made the neighbourhood home to some of the most lucrativesecuritized land in the metropolitan area (Sánchez \& Broudehoux, 2013; De Lisio \& Sodré, 2018). While the newly erected Olympic Fan Zone attracted more movement to the area, women reported "business as usual" for the duration of the Olympic Games. As Fernanda remembered, "We normally open at 10 a.m. and close at 7 p.m., and thought that during the Olympics we would work all day to serve new clientele but the Games had no effect. It was business as usual." (Personal communication, January 9, 2017). Importantly, despite the well-known raid in Niterói, women were not threatened with removal-nor was there an expressed/perceived threat of eviction. With the monthly stipend paid to police, sex businesses were secure downtown. Furthermore, it was noted that to attract additional clientele and seize the mega-moment, at nighttime, women often migrated to (sex) businesses thought to be more populated with tourist men in Vila Mimosa and Copacabana.

\section{Vila Mimosa}

After a decade of demolition and devastation (1970-1980), the Mangue resurfaced near Praça da Bandeira, less than a kilometer from Maracanã Stadium in the West Zone of Rio de Janeiro, before it was resurrected in an abandoned warehouse on Rua Sotero dos Reis. West of the downtown core, outside of the touristic South Zone, Vila Mimosa has remained a vital zone in the sexual landscape despite constant threat of erasure.

For the duration of 2014 FIFA and 2016 IOC parties, local law enforcement enclosed the perimeter so as to secure the main road to Maracanã and divert tourism from the area. Foreign men and women were warned not to roam the less tourist-oriented North Zone. Wreathed with the scent of raw sewage and funk music that ricocheted throughout the block, the area marked the inverse of the more celebrated Brazilian (erotic) brand. On June 6, the Friday before the 2014 FIFA World Cup, AMOCAVIM (the neighbourhood resident and business association) erected a plastic-vinyl billboard in the neighbourhood (see Fig. 4). After the first World Cup match at Maracanã (June 15, Argentina versus Bosnia and Herzegovina), three Argentinean men drove through in a taxi but never stopped. On some kind of private sex safari, each one stared through the closed window at partially clothed women in the street. One woman admitted,

It is common to see a driver come through with a gringo. We occasionally hire them too. They bring in different men; negotiate with us for them. But the Olympics hit us hard. I could barely pay for breakfast, you know? I was fortunate I had this place [laundromat]. It sustained me during the Games. Not prostitution. (Tatiana, personal communication, September 22, 2016)

Not far from the now-deserted national treasure, Maracanã, Vila Mimosa is typically frequented by local (working class) men and the most seasoned sex tourist. The 2014 and 2016 mega-event proved little exception. During FIFA and IOC parties, the neighbourhood hosted migrant-Brazilian women from Niterói and Centro, which triggered a movement of Vila women to Copacabana (discussed next). Overall business remained relatively stable with no noticeable improvement or decline. Similar to those who reported on prostitution at the 2008 Beijing Olympic Games (e.g. Hayes, 2010), it could be estimated that the heavily militarized Maracanã combined with the otherwise destitute state of the immediate area deterred the highly anticipated influx of (foreign) clientele. With 
zero investment in the area aside from the plastic façade, the entire block and the bodies within have been left to rot and decay - atrophy beyond pardon or repair. Bruna, a sex worker in Vila Mimosa for a decade, explained "It was better before in Vila Mimosa. I used to make R $\$ 800 /$ week, now I make $\mathrm{R} \$ 500 /$ week. I charge $\mathrm{R} \$ 50$ (approximately $\$ 25 \mathrm{USD}$ ) to $\mathrm{R} \$ 60$ per session. $\mathrm{R} \$ 10$ is paid to the house. And I keep the rest." (Personal communication, September 1, 2016). With minimal state intrusion into the area and zero public investment, Vila Mimosa is now demonstrative of the slow violence marginal communities are made to endure. Barred from national celebration, women oscillated between Vila Mimosa and the more tourist-oriented South Zone in search of new clientele.

\section{Copacabana}

The world-renowned beachfront of Copacabana-backdrop to British media coverage of FIFA 2014-has served as a (in)famous site for sexual commerce, home to the scant Brazilian bikini and eccentric nightlife. For the duration of the 2014 FIFA World Cup, it housed the FIFA Fan Fest (see Fig. 5), nearest the entrance at Princesa Isabel Avenue, and FIFA executive at the luxurious Copacabana Palace. On the morning of June 12 (opening day), a bar well known to attract foreign men and working women was closed due to an allegation of child sexual exploitation (shown in Fig. 1). Prior to the closure, the owner of the bar was subject to constant police surveillance and harassment, which resulted in the confiscation of his personal computer in 2012, never to be returned. In the aftermath of the closure, the plaza adjacent to the bar absorbed much of the business, with the informal street market capitalizing on the newly displaced, alcohol-seeking clientele.

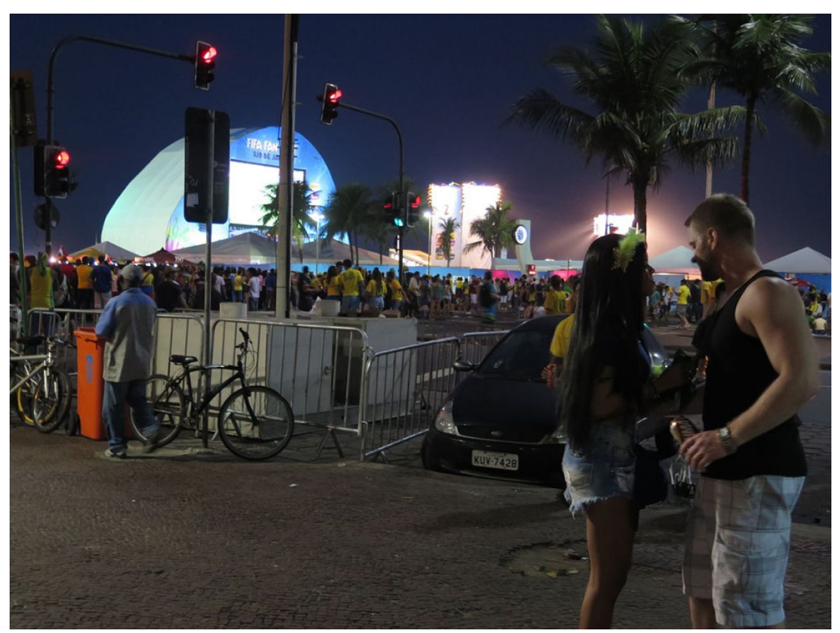

Fig. 5 2014 FIFA Fan Fest in Copacabana, Rio de Janeiro, Brazil. Photo credit: Amanda De Lisio
Youth too occupied the area. Some slept on a discarded Brazilian flag, while the majority worked the area-one child barely tall enough to peer over his trolley made caipirinha after caipirinha (a Brazilian drink made with cachaça, a distilled spirit made from sugarcane) for the gringo mob (see Fig. 6). The women continued to attract foreign clientele and used the now vacant patio area to dress, negotiate, and chat over wi-fi (see Fig. 7). As one woman asserted to a member of the Observatório, "O bar está fechado, mas a internet está funcionando! [The bar might be closed but the wi-fi is working!]." (G. Mitchell, personal communication, July 15, 2014). In unexceptional fashion, the closure mimicked the historic closure of other sex businesses in the area. Help! was (and despite demolition, still is) a notorious nightclub in Copacabana, now home to the not-yet-completed Museum of Imagery and Sound [Museu da Imagem e do Som]. During the 2014 FIFA World Cup, an international media tent was located directly in front of the disco-bar, while the television broadcast was filmed from a newly constructed gantry that positioned the old Help! in the immediate background. The nightclub came to demonstrate the ubiquity of sex work in middle-class Brazilian sociality. Often intermixed with more "respectable" women, working women in Copacabana are free to peruse the scene, meet prospective clientele, without the expectation or demand of official bar/restaurant staff. The closure of Help! triggered a shift in this movement on the beachfront. Women now occupy the area nearest the intersection of Avenida Atlântica and Avenida Prado Júnior, a zone once better known for travesti [transgendered] work. As one woman effectively explained:

People want to end prostitution in Copacabana but they need to understand that will never happen. They close one bar. Another will open. They closed Balcony. The

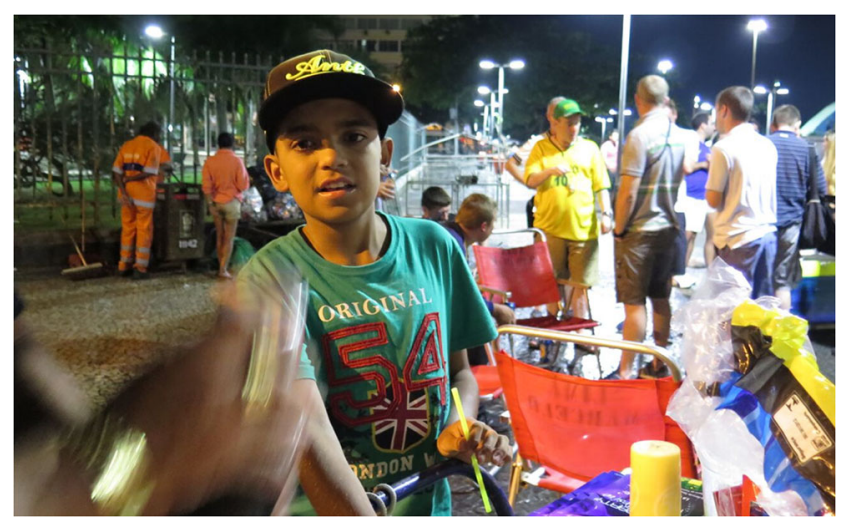

Fig. 6 A boy making caipirinhas (alcoholic drink made with cachaça-a distilled spirit made from sugarcane juice — brown sugar, and lime) in the plaza next to the closed Balcony Bar during the World Cup. Photo credit: Amanda De Lisio 


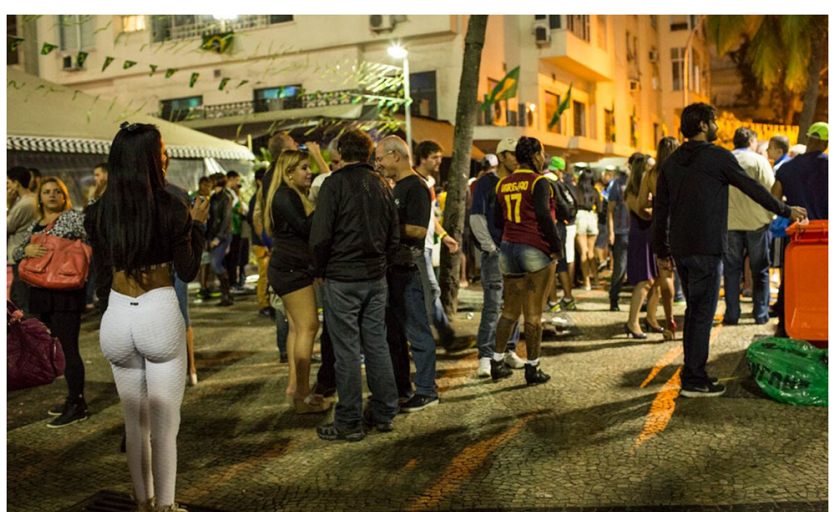

Fig. 7 Business in the plaza adjacent to the Balcony Bar on a fairly typical night during the 2014 FIFA World Cup. Photo credit: Matias Maxx/Vice

ladies went to Mab's. They close Mab's. We will go to Imaculada. They're never going to leave. They'll never eliminate prostitution. They have to understand gringos come to see Rio, the beauty, of course, but also the prostitutes. (Daniele, personal communication, September 22, 2016)

Whilst the sale of sex has indeed survived, even thrived, despite the closure of several sex-related businesses, Copacabana failed to emulate the sexual liberation of Artemis in Berlin, a four-floor multimedia brothel built in time for the 2006 FIFA World Cup, conveniently located next to the stadium subway line. Even though formal businesses continue to benefit from commercial sex, staff and management continue to refuse to admit (let alone celebrate) women-as-working. Whereas businesses used to assert sex work as a legitimate form of labour-even endorse the occurrence on the back of a menu - that is not the case in the current climate. To be visible/marketed as a sex venue is to make the owner vulnerable to the harassment of local law enforcement. Those involved in sexual commerce thus move through nightlife as an "absentpresence" (Walcott, 2003). While these stories could be superficially used to recast marginal women as infinitely barred from urban life, a more intimate look at host realities will more accurately reveal the extent to which revanchist strategies reiterate the never static bodies (and land) in urban space. Consistent across the data are stories of spatial governmentality that target urban space (rather than individual bodies) in reform - and the need for women to be constantly-comfortably displaced. The acceleration of urban construction, with strategies akin to neoliberal acupuncture, proved to (re)enact familiar technologies of governance, yet also cultivated a renewed sense of optimism. By way of conclusion, we thus focus on the research now needed to better understand lived realities of globally-inspired development priorities, in order to inform future legislation, policies, and enforcement strategies.

\section{Concluding Comments}

In this article, we have offered brief, contextual, and evidence-based sketches of the (heterosexual) sexual commerce across 2014 and 2016 host communities in Rio de Janeiro to illustrate the localized and diverse impact of event-led urbanism and entrepreneurial exceptionalism on those involved in adult, consensual, commercial sex. As (arguably) the oldest profession, sex work has forever been embedded within processes of land reform, which variously value and devalue property and place (Hubbard, 2016; Papayanis, 2000). Suggesting such processes accelerate and take specific form in the midst of the contemporary sport mega-event, we demonstrate the manner in which FIFA/IOC offer an institutionalized alibi for local-unelected elite to realize fantasies of (global) capital accumulation through state-sanctioned commodification of urban land. Sex work is appropriated into these itineraries in a unique manner. Whereas certain (sexed) bodies are positioned as "red light" to safe, commodious host cities, and thereby subject to new-albeit-familiar policies of containment, exclusion, or repression-other (sexed) bodies are celebrated in the national "erotic" narrative. Indeed, arbitrarily enforced (prostitution) legislation was resourced to displace certain (sexed) bodies and mobilize a growth coalition of local elite across 2014/2016 host communities.

Nevertheless, the success of the mega-event is contingent upon the performance of a dynamic cast and crew who combine to host a global audience, whether as starlet on the main stage or derelict behind the scene. To such an extent, event exceptionalism is not afforded to all, or experienced by all in the same way. The same is true for sexual commerce. Not all sex (work) is deemed incompatible with the vision of host cities as safe, civilized, sanitized, and tolerant (Hubbard \& Wilkinson, 2015): Some profit from the event and provide valuable leisure opportunities and hospitality rarely acknowledged by any host. As we have suggested, such creative potential will demand constant negotiation with law and order authorities to accommodate the new geographies of repressedinclusion that accompany the international event. Hence, in the future, we advise those interested in sexual diversity studies - those keen to realize cities as sexed - to be mindful of the manner in which sex (similar to sport) is prepackaged in a neoliberal capitalist agenda, and the extent to which this agenda is authentically realized across local communities. Ultimately, as Wetizer (Weitzer, 2010) has warned, future action should be based on empirically 
informed evidence and local histories rather than popular "global" mythologies that coalesce around the sport mega-event.

Funding This study was funded by the Economic and Social Research Council (ES/N018656/1).

\section{Compliance with Ethical Standards}

Conflict of Interest The authors declare that they have no conflict of interest.

Open Access This article is distributed under the terms of the Creative Commons Attribution 4.0 International License (http:// creativecommons.org/licenses/by/4.0/), which permits unrestricted use, distribution, and reproduction in any medium, provided you give appropriate credit to the original author(s) and the source, provide a link to the Creative Commons license, and indicate if changes were made.

\section{References}

Agamben, G. (2005). State of exception. Chicago, IL: University of Chicago Press.

Andranovich, G., Burbank, M. J., \& Heying, C. H. (2001). Olympic cities: Lessons learned from mega-event politics. Journal of Urban Affairs, 23(2), 113-131.

Bird, R., \& Donaldson, R. (2009). "Sex, sun, soccer": Stakeholderopinions on the sex industry in Cape Town in anticipation of the 2010 FIFA Soccer World Cup. Urban Forum, 20(1), 33-46.

Blanchette, T., \& da Silva, A. P. (2010). Seven: Our lady of help: Sex, tourism and transnational movements in Copacabana. Wagadu: A Journal of Transnational Women's and Gender Studies, 8, 144-165.

Blanchette, T., \& da Silva, A. P. (2016). "Brazil has its eye on you": Sexual panic and the threat of sex tourism in Rio de Janeiro during the FIFA World Cup, 2014. Brasiliana-Journal for Brazilian Studies, 4(2), 411-454.

Caulfield, S. (1997). The birth of Mangue: Race, nation, and the politics of prostitution in Rio de Janeiro, 1850-1942. In D. Balderston \& D. Guy (Eds.), Sex and sexuality in Latin America (pp. 86-100). New York, NY: New York University Press.

Cornelissen, S., \& Solberg, E. (2007). Sport mobility and circuits of power: The dynamics of football migration in Africa and the 2010 World Cup. Politikon, 34(3), 295-314.

De Lisio, A., \& Sodré, J. G. R. (2018). FIFA/IOC-sanctioned development and the imminence of erotic space. Bulletin of Latin American Research. https://doi.org/10.1111/blar.12747

Deering, K. N., Lyons, T., Feng, C. X., Nosyk, B., Strathdee, S. A., Montaner, J. S., \& Shannon, K. (2013). Client demands for unsafe sex: The socio-economic risk environment for HIV among street and off-street sex workers. Journal of Acquired Immune Deficiency Syndromes (1999), 63(4), 522.

Dewey, S., \& St. Germain, T. (2014). "It depends on the cop:" Streetbased sex workers' perspectives on police patrol officers. Sexuality Research \& Social Policy, 11(3), 256-270. https://doi.org/10.1007/ s13178-014-0163-8

Gaffney, C. (2010). Mega-events and socio-spatial dynamics in Rio de Janeiro, 1919-2016. Journal of Latin American Geography, 9(1), 7-29.

Hammersley, M., \& Atkinson, P. (2007). Ethnography: Principles in practice. London: Routledge.
Haviv, N. (2016). Reporting sexual assaults to the police: The Israeli BDSM community. Sexuality Research \& Social Policy, 13(3), 276-287. https://doi.org/10.1007/s13178-016-0222-4

Hayes, V. (2010). Human trafficking for sexual exploitation at world sporting events. Chicago-Kent Law Review, 85, 1105.

Hodkinson, S. (2011). Housing regeneration and the private finance initiative in England: Unstitching the neoliberal urban straightjacket. Antipode, 43(2), 358.

Hubbard, P. (2016). Sex work, urban governance and the gendering of cities. In G. Brown \& K. Browne (Eds.), The Routledge research companion to geographies of sex and sexualities. London: Routledge.

Hubbard, P., \& Wilkinson, E. (2015). Welcoming the world? Hospitality, homonationalism, and the London 2012 Olympics. Antipode, 47(3), 598-615.

Judd, D., \& Simpson, D. (2003). Reconstructing the local state: The role of external constituencies in building urban tourism. The American Behavioral Scientist, 46(8), 1056-1069.

Kennelly, J., \& Watt, P. (2011). Sanitizing public space in Olympic host cities: The spatial experiences of marginalized youth in 2010 Vancouver and 2012 London. Sociology, 45(5), 765-781.

Loopmans, M., \& Van den Broeck, P. (2011). Global pressures, local measures: The re-regulation of sex work in the Antwerp Schipperskwartier. Tijdschrift voor Economische en Sociale Geografie, 102(5), 548-561.

Maguire, J., \& Pearton, R. (2000). The impact of elite labour migration on the identification, selection and development of European soccer players. Journal of Sports Sciences, 18(9), 759-769.

Matheson, C. M., \& Finkel, R. (2013). Sex trafficking and the Vancouver Winter Olympic Games: Perceptions and preventative measures. Tourism Management, 36, 613-628.

Mathieu, L. (2012). An ambiguous compassion: Policing and debating prostitution in contemporary France. Sexuality Research \& Social Policy, 9(3), 203-211. https://doi.org/10.1007/s13178-012-0082-5

Mitchell, G. (2011). TurboConsumers ${ }^{\mathrm{TM}}$ in paradise: Tourism, civil rights, and Brazil's gay sex industry. American Ethnologist, 38(4), 666-682.

Mitchell, G. (2016). Evangelical ecstasy meets feminist fury: Sex trafficking, moral panics, and homonationalism during global sporting events. GLQ: A Journal of Lesbian and Gay Studies, 22(3), 325357.

Nyeck, S. N. (2013). Mobilizing against the invisible: Erotic nationalism, mass media, and the 'paranoid style' in Cameroon. In S. N. Nyeck \& M. Epprecht (Eds.), Sexual diversity in Africa: Politics, theory, citizenship (pp. 151-169). Montreal, Quebec: McGill-Queens University Press.

Ong, A. (2006). Neoliberalism as exception: Mutations in citizenship and sovereignty. Chapel Hill, NC: Duke University Press.

Papayanis, M. A. (2000). Sex and the revanchist city: Zoning out pornography in New York. Environment and Planning D: Society and Space, 18(3), 341-353.

Paton, K., Mooney, G., \& McKee, K. (2012). Class, citizenship and regeneration: Glasgow and the Commonwealth Games 2014. Antipode, 44(4), 1470-1489.

Pattisson, P. (2013). Revealed: Qatar's world cup "slaves." The Guardian. Retrieved from https://www.theguardian.com/world/ 2013/sep/25/revealed-qatars-world-cup-slaves.

Pavoni, A. (2013). Exceptional tunings: Controlling urban events (unpublished doctoral dissertation). London, Emgland: University of Westminster.

Pavoni, A., \& Citroni, S. (2016). An ethnographic approach to the taking place of the event. In I. R. Lamond \& L. Platt (Eds.), Critical event studies: Approaches to research (pp. 231-251). London: Palgrave Macmillan UK.

Peck, J., Theodore, N., \& Brenner, N. (2009). Postneoliberalism and its malcontents. Antipode, 41(S1), 94-116. 
Pink, S. (2013). Doing visual ethnography. London: Sage.

Puri, J. (2016). Sexualizing neoliberalism: Identifying technologies of privatization, cleansing, and scarcity. Sexuality Research \& Social Policy, 13(4), 308-320.

Raco, M. (2012). The privatization of urban development and the London 2012 Olympics. City: Analysis of Urban Trends, Theory, Policy, Action, 16(4), 452-460.

Rancière, J. (1995). Disagreement: Politics and philosophy. Minneapolis: University of Minnesota Press.

Richter, M., Luchters, S., Ndlovu, D., Temmerman, M., \& Chersich, M. F. (2012). Female sex work and international sport events - no major changes in demand or supply of paid sex during the 2010 Soccer World Cup: A cross-sectional study. BMC Public Health, 12(1), 763.

Sánchez, F., \& Broudehoux, A. M. (2013). Mega-events and urban regeneration in Rio de Janeiro: Planning in a state of emergency. International Journal of Urban Sustainable Development, 5(2), 132-153.

Silk, M. (2007). Come downtown and play. Leisure Studies, 26(3), 253277.

Silk, M. (2011). Towards a sociological analysis of London 2012. Sociology, 45(5), 733-748.

Silk, M. (2014). The London 2012 Olympics: The cultural politics of urban regeneration. Journal of Urban Cultural Studies, 1(2), 273 294.

Silk, M., \& Amis, J. (2005). Sport tourism, cityscapes and cultural politics. Sport in Society, 8(2), 280-301.
Silk, M., \& Andrews, D. (2008). Managing Memphis: Governance and spaces of inequality. Social Identities, 14(3), 395-414.

Sloss, C., \& Harper, G. (2010). Legal service needs and utilization of women who trade sex. Sexuality Research \& Social Policy, 7(3), 229-241. https://doi.org/10.1007/s13178-010-0025-y

Smith, N. (1996). The new urban frontier: Gentrification and the revanchist city. New York: Routledge.

Smith, A., \& Fox, T. (2007). From 'event-led' to 'event-themed' regeneration: The 2002 Commonwealth Games legacy programme. Urban Studies, 44(5-6), 1125-1143.

Torres Ribeiro A.C. (2006). A acumulação primitiva do Capital Simbólico. In Jeudi, H.P., \& Berenstein, P.J. (Eds.). Corpos e Cenários Urbanos: Territórios Urbanos e Politicas Culturais. Salvador: Press of the Federal University of Bahia (EDUFBA).

Vonn, M. (2009). CCTV and the 2010 Vancouver games: Spatial tactics and political strategies. Case W Res J Int'l L, 42, 595.

Wacquant, L. (2008). The militarization of urban marginality: Lessons from the Brazilian metropolis. International Political Sociology, 2(1), 56-74.

Walcott, R. (2003). Black like who?: Writing black Canada. Insomniac Press

Weitzer, R. (2010). The mythology of prostitution: Advocacy research and public policy. Sexuality Research \& Social Policy, 7(1), 15-29.

Whitson, D., \& Macintosh, D. (1996). The global circus: International sport, tourism and the Marketing of Cities. Journal of Sport \& Social Issues, 20, 239-257. 